\title{
BIOLOGICAL AND CHEMICAL CONTROL OF DAMPING -OFF OF PEPPER CAUSED BY Sclerotium rolfsii Sacc.
}

(Received: 7.4.2010 )

\author{
By \\ M. S. Mansour, M. F. Attia and N. H. Mohamed \\ Plant Pathology Department, Faculty of Agriculture, Cairo University, Giza, Egypt.
}

\begin{abstract}
A large number of diseases has been reported to attack pepper plants in Egypt; of these, damping - off caused by Sclerotium rolfsii Sacc. (The sclerotial state of Athelia rolfsii Curtz) is the most common. Four fungi, i.e. Fusarium solani Mart, Fusarium oxysporum Schlecht, S. rolfsii and Rhizoctonia solani Kuhn were isolated from rotted roots of pepper plants. Pathogenicity test indicated that the highest percentages of pre- and post-emergence damping -off were recorded on pepper and tomato plants sown in soil infested with $S$. rolfsii, $R$. solani, and $F$. solani. In vitro studies showed that Trichoderma harzianum Rifai and Bacillus subtilis Ehrenberg caused clear inhibition to $S$. rolfsii growth. In vivo studies, treatment of pepper seeds with either T. harzianum or B. subtilis showed a significant decrement in the infection of pepper plants by $S$. rolfsii. Some fungicides, i.e., Vitavax- Thiram, Rizolex T, Tashgarin and Moncerin completely inhibited the growth of $S$. rolfsii at $100 \mathrm{ppm}$ concentration. In vivo studies, treatment of pepper seeds with any of the aforementioned fungicides at the recommended dose caused significant decrement in the infection of pepper plants by $S$. rolfsii.
\end{abstract}

Key words: Bacillus, chemical control, damping-off, pepper, root-rot and Trichoderma.

\section{INTRODUCTION}

Genus Sclerotium is one of the most important soil -borne fungi spreading in Egypt as well as in other parts of the world (Attia and Abada, 1994; Okereke and Wokocha, 2006 and Daami et al., 2007).

S. rolfsii Sacc. has been reported as the causal organism of damping - off, root-,stem-, pod-rots and reduce of fresh and dry weight of Solanaceous plants (Okereke and Wokocha, 2007; Abiaa and Muhammed, 2008 ; Jin- hyeuk et al., 2008 and Maurya et al.,2008).

Biological control of plant pathogens is an attractive alternative method of modern agriculture. It does not depend on chemical fungicides which cause environmental pollution and development of fungicide resistant strains. $T$. harzianum and B. subtilis have long been known for their capacity to reduce plant diseases caused by Sclerotium rolfsii (Muhammad and Amusa, 2003 and Muskhazli and Nor Farizan, 2006).

Chemical control of damping -off and root rot of Solanaceous plants was also investigated by some researchers (Attia and Abada, 1994; Abd ElKareem et al., 2004; Yaqub and Saleem, 2005; EL-Mohamedy et al., 2006; Palaiah et al.,2007 and Maurya et al., 2008).
The present investigation was carried out to throw light on the causes of pre- and post emergence damping -off and root-rot of pepper. In addition, attempts to minimize infection with the aforementioned diseases were investigated.

\section{MATERIALS AND METHODS}

\subsection{Isolation, purification and identification of the isolated fungi}

Samples of naturally infected pepper plants showing the typical symptoms of damping-off, wilt, stem-rot and root-rot were collected from the Agricultural Experiments and Research Station of Faculty of Agric., Cairo Univ. Rotten roots were cut into small pieces, surface sterilized with $2 \%$ sodium hypochlorite for $3 \mathrm{~min}$, rinsed in sterilized water, dried between sterilized filter papers and transferred on PDA plates. The plates were incubated at $25^{\circ} \mathrm{C}$ and daily examined. Resulting fungi were picked up and purified using the hyphal tip technique. The purified fungi were identified according to their morphological features to the genus and/or the species level using the descriptions of Snyder and Hansen (1940); Gilman (1957); Booth and Waterston (1964); Booth (1971) and Barnett and Hunter (1971). Pure 
cultures were kept in a refrigerator on PDA slants at $5-10^{\circ} \mathrm{C}$ for further studies.

\subsubsection{Pathogenicity test}

Pots $(25 \mathrm{~cm}$ in diam.) filled with sterilized soil were individually infested with $5 \%(\mathrm{w} / \mathrm{w})$ inoculum level of the desired fungus grown in sterilized bottles $500 \mathrm{ml}$, containing sand barley medium $(25 \mathrm{~g}$ clean sand $+75 \mathrm{~g}$ barley grains +100 $\mathrm{ml}$ water). Inoculum- free pots were used as control. Seeds (5/pot) of either pepper cv. Baladi or tomato cv. Super Strain B were individually sown in the pots (3/replicates). After two and six weeks from planting, the number of dead plants, as a result of seedlings infection by Pre -and post emergence damping-off, respectively was recorded and the average percentage was calculated. In addition, the number of dead plants due to infection by root-rot was recorded 60 days after sowing and disease severity was estimated according to Salt (1981). Reisolation was carried out from the artificially infected roots of tested plants to confirm pathogenicity test.

\subsection{Biological control}

\subsubsection{In vitro studies}

Two methods were carried out using two bioagents, (occasionally isolated during trials from the rotted roots) i.e. B. subtilis (provided by Microbiology Dept., Ain Shams Univ.) and $T$. harzianum. PDA plates $(90 \mathrm{~mm})$ were inoculated at $30^{\circ} \mathrm{C}$ each with disc of $S$. rolfsii $(5 \mathrm{~mm}$ in diam.), two days later, either $B$.subtilis (streaking or filtration in wells inside the plates) or disc of $T$. harzianum were put opposite the growth of $S$ .rolfsii. Plates inoculated with $S$. rolfsii only were used as a control. Inhibition zones were measured when the fungal growth, in the control plates reached the edge of the plate after four days.

\subsection{In vivo studies}

This experiment was carried out at the greenhouse of Fac. of Agric., Cairo Univ. Seeds (30 seeds /treatment) for each of the four pepper cvs Sweet pepper, Long Red Cayenne, California Wonder and Anaheim $\mathrm{M}$ were coated with either B. subtilis (seeds were immersed in $1.0 \%$ glue as sticker for $2 \mathrm{~min}$, drained well then soaked in the culture $48 \mathrm{~h}$ for $10 \mathrm{~min}$.) or $T$. harzianum (seeds were washed with distilled water for a few sec, air dried, rolling on culture plates then air-dried), sown in the soil infested with $S$. rolfsii. Inoculumfree treatments were used as control. The number of pre- and post -emergence damping -off plants was recorded 2 and 6 weeks after planting, respectively and the average percentage was calculated.

\subsection{Chemical control}

\subsubsection{In vitro studies}

Six concentrations ( $0,5,10,25,50$ and $100 \mathrm{ppm}$ ) representing the four fungicides, i.e. Rizolex T, Vitavax Thiram, Tashgrin and Moncerin were added to PDA flasks $\left(40^{\circ} \mathrm{C}\right)$ according to their active ingredients (Table 1) and

Table (1) Active ingredient and rate of using tested fungicides.

\begin{tabular}{|l|l|l|}
\hline Trade name & $\begin{array}{l}\text { Common } \\
\text { name }\end{array}$ & Rate of using \\
\hline Moncerin 25\% WP & Pencycuron & $\mathbf{3}$ / kg seed \\
\hline $\begin{array}{l}\text { Vitavax Thiram } \\
\text { 200 75\% WP }\end{array}$ & $\begin{array}{l}\text { carboxin+ } \\
\text { thiram }\end{array}$ & $\begin{array}{l}1-3 \text { g / kg } \\
\text { seed }\end{array}$ \\
\hline Rizolex -T 50\% WP & $\begin{array}{l}\text { tolclofos- } \\
\text { methyl }\end{array}$ & $\mathbf{3 g} / \mathbf{k g}$ seed \\
\hline Tashgarin 30\% SL & Hemexazol & $\mathbf{1 ~ c m ~ / ~ l i t . ~}$ \\
\hline
\end{tabular}

poured in Petri plates (3 replicate plates). Petri plates $(90 \mathrm{~mm})$ were inoculated at $30^{\circ} \mathrm{C}$ with disks (5mm in diam) of $S$ rolfii (4 days old). Radial growth was recorded when the fungal growth reached the edge of the control.

\subsubsection{In vivo studies}

Seeds of pepper cvs Sweet pepper, Long Red Cayenne, California Wonder and Anaheim M were individually coated, seeds were immersed in $1.0 \%$ glue as sticker for $2 \mathrm{~min}$, drained well then mixed with the desired fungicide, i.e. Rizolex- T, Vitavax -Thiram ,Tashgrin (seeds were coated by soaked for $10 \mathrm{~min}$. then air dry)and Moncerin at the recommended dose (Table 1). Seeds (30 seeds/treatment) were sown in speedling trays filled with soil infested with 5\% (W: W) S. rolfsii. Inoculum- free cells were used as control. Pre- and post -emergence damping - off were recorded 2 and 6 weeks after planting, respectively.

\section{Statistical analysis}

The obtained data were statistically evaluated according to Snedecor and Cochran (1967) and the L.S.D. was assessed according to Fisher (1948).

\section{RESULTS}

\subsection{Isolation, purification and identification of the isolated fungi}

The isolated fungi were purified and identified to the genus and/or the species level according to their morphological characters. Results (Table 2) indicate that Sclerotium rolfsii Sacc. was the most dominant followed by Fusarium solani (Mart.) Sacc., Fusarium oxysporum Schlecht and Rhizoctonia solani J.G. Kühn. The corresponding percentages of their frequency were $23.61,15.28,13.89$ and $13.89 \%$, respectively. Fungi belonging to the genera Alternaria, Aspergillus, Pythium and Trichoderma were also 
isolated. Accordingly, fungi which showed high frequency were tested for their pathological potentialities. Meanwhile, T. harzianum was used in the biological control experiments.

Table (2): Occurrence and frequency of the fungi isolated from pepper plants showing dampingoff and root-rot symptoms collected from the Agricultural Experiments and Researches Station, Fac. of Agric., Cairo Univ.

\begin{tabular}{|c|c|c|}
\hline Isolated fungi & $\begin{array}{l}\text { No. of } \\
\text { isolates }\end{array}$ & Frequency, \% \\
\hline Alternaria sp. & 9 & 12.50 \\
\hline Aspergillus niger & 4 & 5.56 \\
\hline Aspergillus flavus & 2 & 2.78 \\
\hline Fusarium $\mathrm{sp}$ & 2 & 2.78 \\
\hline F. oxysporum & 10 & 13.89 \\
\hline F. solani & 11 & 15.28 \\
\hline Pythium sp & 6 & 8.32 \\
\hline Rhizoctonia solani & 10 & 13.89 \\
\hline Sclerotium rolfsii & 17 & 23.61 \\
\hline $\begin{array}{l}\text { Trichoderma } \\
\text { harzianum }\end{array}$ & 1 & 1.39 \\
\hline Total & 72 & - \\
\hline
\end{tabular}

\subsection{Pathogenicity tests}

Data in Table (3) show that the highest percentages of pre- and post -emergence damping -off were recorded on pepper and tomato plants sown in soil infested with any of the three fungi, i.e., S .rolfsii, $R$. solani and $F$.solani. On the other hand, the highest percentages of disease severity were recorded on pepper and tomato plants sown in a soil infested with $S$. rolfsii, $F$. oxysporum, $F$. solani and $R$. solani. Plants grown in the soil infested with $T$. harzianum, or in the control treatment were healthy. Due to the high pathogenic potentialities, of $S$.rolfsii it was selected for further studies.

\subsection{Biological control}

3.3.1. In vitro studies

3.3.1.1. Antagonistic effect of Bacillus subtilis.

Data in Table (4) show that the largest inhibition zone $(15 \mathrm{~mm})$ was recorded in plates inoculated with $S$. rolfsii and streaked with $B$. subtilis compared to those inoculated with filtration of $B$. subtilis.

\subsubsection{Antagonistic effect of T. harzainum}

Data in Table (5) indicate that $T$. harzianum reduced the growth $(24 \mathrm{~mm})$ of $S$. rolfsii as compared to the treatment inoculated with $S$. rolfsii only (90mm).

\subsection{In vivo studies}

\subsubsection{Antagonistic effect of $B$. subtilis}

Data in Table (6) show that sowing seeds of four pepper cvs. coated by $B$. subtilis decreased the incidence percentages of damping- off on pepper plants, especially var. California Wonder' and 'Anaheim $\mathrm{M}$ ' compared to the treatments inoculated with S. rolfsii only.

\subsection{Antagonistic effect of T. harzianum}

Data in Table (7) show that coating seeds of pepper cultivar with $T$. harzianum decreased the percentages of damping -off of pepper plants of the tested cultivars, especially cv. 'California Wonder' and 'Anaheim $\mathrm{M}$ ' compared to the treatment inoculated with $S$. rolfsii only.

Data also, show that all the tested pepper cvs. were susceptible to infection by $S$ rolfsii. Sweet pepper and Long Red Cayenne were the most susceptible cvs. to the infection by $S$ rolfsii. Meanwhile, the varieties 'California Wonder' and 'Anaheim $\mathrm{M}$ ' showed the lowest infection (Tables 6.7).

\subsection{Chemical control}

\subsubsection{In vitro studies}

Data in Table (8) demonstrate that no growth of $S$ rolfsii was recorded when the tested fungicides, i.e., Rizolex -T, Vitavax -Thiram, Tashgrin and Moncerin were added at 100ppm to PDA medium, while fungal growth reached $90 \mathrm{~mm}$ when $5 \mathrm{ppm}$ concentration was used at $5 \mathrm{ppm}$. On the other hand, the least inhibition of the fungal growth $(72 \mathrm{~mm})$ was recorded when Tashgrin was added to PDA medium at 50ppm followed by Vitavax - Thiram and Moncerin at the same concentration.

\subsubsection{In vivo studies}

Data presented in Table (9) indicate that all the tested fungicides, i.e. Rizolex-T, Vitavax- Thiram, Tashgrin and Moncerin decreased pre- and post emergence damping- off of pepper plants of the tested cultivars. In all cases, Vitavax -Thiram gave the highest decrement of pre- and post- emergence damping -off of all pepper cvs. especially pepper cultivars. 'Anaheim M' and California Wonder' followed by Rizolex-T.

\section{DISCUSSION}

Pepper plants (Capsicum annuum L.) are vulnerable to attacks with serious diseases, among which damping-off and root rot are widespread in Egypt (Attia and Abada, 1994; Abada,1994 and Abd El-Kareem et al., 2004) and in many other countries (Serra \& Sliva Gilson, 2005) causing a considerable reduction of either the number of plants or fruit yield.

In the light of the present findings, Sclerotium rolfsii Sacc. (The sclerotial state of Athelia rolfsii Curtz) showed the highest frequency followed by Fusarium solani Mart, Fusarium oxysporum Schlecht and Rhizoctonia solani Kuhn. All the tested fungi, except Trichoderma harzianum Rifai 
Table (3): Effect of some fungi isolated from rotted-roots of pepper on damping - off and root rot diseases of pepper and tomato plants under greenhouse conditions.

\begin{tabular}{|l|l|l|l|l|l|l|l|l|}
\hline \multirow{2}{*}{ Tested fungi } & \multicolumn{2}{l}{$\begin{array}{l}\text { Pre-emergence* } \\
\text { damping-off, \% }\end{array}$} & \multicolumn{2}{l}{$\begin{array}{l}\text { Post-emergence** } \\
\text { damping-of, \% }\end{array}$} & \multicolumn{2}{l|}{ Plant survival, \%** } & \multicolumn{2}{l|}{ Disease severity, \% } \\
\cline { 2 - 10 } & Pepper & Tomato & Pepper & Tomato & Pepper & Tomato & Pepper & Tomato \\
\hline F. solani & $\mathbf{2 6 . 6 7}$ & $\mathbf{3 3 . 3 3}$ & $\mathbf{3 3 . 3 3}$ & $\mathbf{1 3 . 3 3}$ & $\mathbf{4 0 . 0 0}$ & $\mathbf{5 3 . 3 4}$ & $\mathbf{5 0 . 0 0}$ & $\mathbf{4 1 . 6 0}$ \\
\hline F. oxysporum & $\mathbf{2 0 . 0 0}$ & $\mathbf{2 0 . 0 0}$ & $\mathbf{4 0 . 0 0}$ & $\mathbf{2 0 . 0 0}$ & $\mathbf{4 0 . 0 0}$ & $\mathbf{4 0 . 0 0}$ & $\mathbf{5 8 . 3 3}$ & $\mathbf{4 1 . 6 7}$ \\
\hline R. solani & $\mathbf{3 3 . 3 3}$ & $\mathbf{3 3 . 3 3}$ & $\mathbf{2 0 . 0 0}$ & $\mathbf{2 6 . 6 7}$ & $\mathbf{4 6 . 6 7}$ & $\mathbf{4 0 . 0 0}$ & $\mathbf{3 3 . 3 3}$ & $\mathbf{1 6 . 6 7}$ \\
\hline S. rolfsii & $\mathbf{4 0 . 0 0}$ & $\mathbf{3 3 . 3 3}$ & $\mathbf{2 6 . 6 7}$ & $\mathbf{2 6 . 6 7}$ & $\mathbf{3 3 . 3 3}$ & $\mathbf{4 0 . 0 0}$ & $\mathbf{5 8 . 3 3}$ & $\mathbf{5 8 . 3 3}$ \\
\hline T. harzianum & $\mathbf{0 . 0 0}$ & $\mathbf{0 . 0 0}$ & $\mathbf{0 . 0 0}$ & $\mathbf{0 . 0 0}$ & $\mathbf{0 . 0 0}$ & $\mathbf{0 . 0 0}$ & $\mathbf{0 . 0 0}$ & $\mathbf{0 . 0 0}$ \\
\hline
\end{tabular}

Table (4): Antagonistic effect of $B$. subtilis, used as streaking and filtration against Sclerotium rolfsii, 4 days after incubation at $30 \pm{ }^{\circ} \mathrm{C}$.

\begin{tabular}{|l|l|l|}
\hline \multirow{2}{*}{ Treatments } & \multicolumn{2}{|l|}{$\begin{array}{l}\text { Inhibition zones }(\mathbf{m m}) \text { on } \\
\text { the plates }\end{array}$} \\
\cline { 2 - 3 } & Culture & Filtration \\
\hline $\begin{array}{l}\text { S.rolfsii+ } B . \\
\text { subtilis }\end{array}$ & $\mathbf{1 5}$ & $\mathbf{1 0}$ \\
\hline S.rolfsii & $\mathbf{0 . 0}$ & $\mathbf{0 . 0}$ \\
\hline
\end{tabular}

Table (5): Antagonistic activity of Trichoderma harzianum against Sclerotium rolfsii, 4 days after incubation at $30 \pm{ }^{\circ} \mathrm{C}$.

\begin{tabular}{|c|c|}
\hline Treatments & $\begin{array}{c}\text { Linear growth }(\mathbf{m m}) \\
\text { of } S \text {. rolfsii }\end{array}$ \\
\hline $\begin{array}{c}\text { S. rolfsii+ } T . \\
\text { harzianum }\end{array}$ & $\mathbf{2 4}$ \\
\hline S. rolfsii & $\mathbf{9 0}$ \\
\hline
\end{tabular}

were able to colonize the roots of pepper cv. Baladi and tomato cv. Super Strain B inducing damping - off and root rot symptoms.

The highest percentages of pre- and postemergence damping -off were recorded on pepper cv. Baladi and tomato cv. Super strain B sown in soil infested with S.rolfsii followed by $F$. solani, $R$.solani and F. oxysporum. On the other hand, the highest percentages of disease severity were recorded on pepper and tomato plants sown in soil infested with S.rolfsii, F. oxysporum and F.solani. The results confirmed those reported by Yaqub and Saleem (2005) and Okereke and Wokocha (2006).

Data of the present investigation showed that all the tested pepper cvs. were susceptible to infection by $S$. rolfsii. Pepper cvs. 'Sweet pepper' and 'Long Red Cayenne' were severely infected by damping -off, while cvs 'California Wonder" and 'Anaheim $\mathrm{M}$ ' showed the lowest infection. In an attempt to reduce infection by S. rolfsii, some experiments were carried out under the greenhouse conditions using two bioagents, i.e. B. subtilis and $T$. harzianum, in addition to four fungicides.

Data obtained herein indicated that the inhibition zone was increased when the culture of B. subtilis was used as an antagonistic agent more than when its filtrate was used. The largest inhibition zone $(15 \mathrm{~mm})$ was recorded in the plates of $S$. rolfsii streaked with Bacillus subtilis compared to those inoculated with S. rolfsii and $B$. subtilis used as filtration in wells $(5 \mathrm{~mm})$. These results are in agreement with Muhammad and Amusa, (2003).

B. subtilis inhibited the mycelia growth of S. rolfsii. Two mechanisms intrupt that action. One might be the production of biologically active metabolites, which inhibited the growth of the pathogens. The other might be its rapid growth and spread on the moist surfaced agar plates, which prevented the establishment of the pathogens. A lytic factor has been reported to be located in walls of the strains of $B$. subtilis. Young et al. (1974) suggested that this might have diffused out into the surrounding medium, causing the zones of inhibition observed.

Coating pepper seeds with $B$. subtilis decreased the percentages of damping- off of the tested cvs. especially cvs. California Wonder and Anaheim M compared to the treatments inoculated with S. rolfsii only. These results are in agreement with Palaiah et al., (2007).

In this study, it was clear that $T$. harzianum reduced the growth of $S$. rolfsii compared to the treatments inoculated with $S$. rolfsii only. These results are in agreement with those given by $\mathrm{Di}$ Pietro (1995) and Bankole \& Adebanjo (1998).

$T$. harzianum is known to produce extracellular cell wall degrading enzymes such as chitinases, $\beta$-1, 3-glucanases and cellulases which 
Table (6): Effect of using $B$. subtilis on the incidence of damping -off of some pepper cvs. caused by $S$. rolfsii, greenhouse experiment.

\begin{tabular}{|c|c|c|c|c|c|c|c|c|c|c|c|c|}
\hline \multirow{3}{*}{ Treatments(A) } & \multicolumn{12}{|c|}{ \% Damping- off of cvs.(B) } \\
\hline & \multicolumn{3}{|c|}{ Pepper 'Sweet pepper' } & \multicolumn{3}{|c|}{ Pepper 'Long Red Cayenne' } & \multicolumn{3}{|c|}{ Pepper 'California wonder' } & \multicolumn{3}{|c|}{ 'Pepper Anaheim M' } \\
\hline & Pre-* & $\underset{* * *}{\text { Post- }}$ & 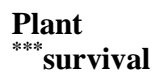 & Pre-* & $\underset{* * *}{\text { Post- }}$ & $\begin{array}{l}\text { Plant } \\
{ }^{* * *} \text { survival }\end{array}$ & Pre-* & Post-"* & $\begin{array}{l}\text { Plant } \\
{ }_{* *}^{*} \text { survival }\end{array}$ & Pre-* & Post- ${ }^{* *}$ & $\begin{array}{l}\text { Plant } \\
{ }_{* * *}^{*} \text { survival }\end{array}$ \\
\hline S.rolfsii+ B. subtilis & 23.33 & 13.33 & 63.34 & 23.33 & 10.00 & 63.64 & 23.33 & 6.67 & 70.00 & 23.33 & 6.67 & 70.00 \\
\hline S.rolfsii & 100.00 & 0.00 & 0.00 & 93.33 & 6.67 & 0.00 & 80.00 & 20.00 & 0.00 & 73.33 & 26.67 & 0.00 \\
\hline B. subtilis & $\mathbf{0 . 0 0}$ & $\mathbf{0 . 0 0}$ & 100.00 & 0.00 & 0.00 & 100.00 & 0.00 & 0.00 & 100.00 & 0.00 & 0.00 & 100.00 \\
\hline $\begin{array}{l}\text { Control } \\
\text { (Non -infested soil) }\end{array}$ & $\mathbf{0 . 0 0}$ & $\mathbf{0 . 0 0}$ & 100.00 & $\mathbf{0 . 0 0}$ & $\mathbf{0 . 0 0}$ & 100.00 & $\mathbf{0 . 0 0}$ & $\mathbf{0 . 0 0}$ & 100.00 & 0.00 & 0.00 & 100.00 \\
\hline
\end{tabular}

L.S.D. (0.05) for:

Pre-emergence $(\mathbf{A} \times \mathbf{B})=0.01 \quad$ Post - emergence $(A \times B)=0.01$

*Assessed 2 weeks after sowing. $\quad$ ** Assessed 6 weeks after sowing.

Table (7) : Effect of treating pepper seeds by T. harzianum on the incidence of damping -off caused by $S$.rolfsii .

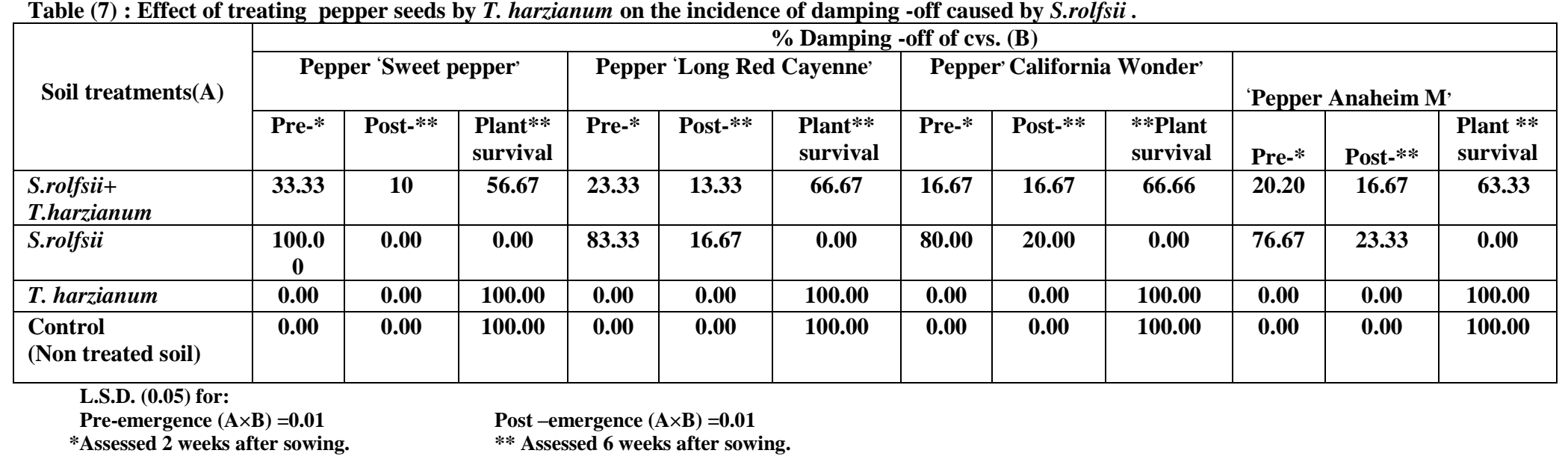


Table (8): Effect of some fungicides on the linear growth (mm) of S. rolfsii, 4 days after incubation at $30 \pm{ }^{\circ} \mathrm{C}$.

\begin{tabular}{|c|c|c|c|c|c|c|c|}
\hline \multirow[t]{2}{*}{ Tested fungicides } & \multicolumn{6}{|c|}{ Linear growth (mm) at the concentrations (ppm). } & \multirow{2}{*}{$\mathbf{X}^{-}$} \\
\hline & $\mathbf{0 . 0}$ & 5 & 10 & 25 & $\mathbf{5 0}$ & 100 & \\
\hline Moncerin & 90 & 90 & 90 & 60 & 32 & $\mathbf{0 . 0}$ & 60.33 \\
\hline Vitavax/ Thiram & 90 & 90 & 90 & 90 & 45 & $\mathbf{0 . 0}$ & 67.5 \\
\hline Rizolex-T & 90 & 90 & 61 & 31 & 28 & $\mathbf{0 . 0}$ & 50 \\
\hline Tashgarin & 90 & 90 & 78 & 74 & 72 & 0.0 & 67.33 \\
\hline $\mathbf{X}^{-}$ & 90 & 90 & 79.75 & 71.25 & 44.25 & 0.0 & 57.27 \\
\hline
\end{tabular}

Table (9): Effect of treatment pepper seeds by some fungicides on the incidence of damping-off caused by $S$. rolfsii.

\begin{tabular}{|c|c|c|c|c|c|c|c|c|c|c|c|c|}
\hline \multirow{3}{*}{$\begin{array}{l}\text { Treatments } \\
\text { (A) }\end{array}$} & \multicolumn{12}{|c|}{$\%$ Incidence of damping- off of pepper cvs. } \\
\hline & \multicolumn{3}{|c|}{ Pepper 'Sweet pepper' } & \multicolumn{3}{|c|}{$\begin{array}{l}\text { Pepper 'Long Red } \\
\text { Cayenne' }\end{array}$} & \multicolumn{3}{|c|}{$\begin{array}{l}\text { Pepper 'California } \\
\text { Wonder' }\end{array}$} & \multicolumn{3}{|c|}{ Pepper 'Anaheim M' } \\
\hline & Pre-* & $\begin{array}{l}\text { Post- } \\
* *\end{array}$ & $\begin{array}{l}\text { Plant** } \\
\text { survival }\end{array}$ & $\begin{array}{l}\text { Pre- } \\
*\end{array}$ & $\begin{array}{l}\text { Post- } \\
* *\end{array}$ & $\begin{array}{l}\text { Plant } \\
* * \\
\text { survival } \\
\end{array}$ & $\begin{array}{l}\text { Pre- } \\
*\end{array}$ & $\begin{array}{l}\text { Post- } \\
* *\end{array}$ & $\begin{array}{l}\text { Plant } \\
* * \\
\text { survival } \\
\end{array}$ & $\begin{array}{l}\text { Pre- } \\
*\end{array}$ & $\begin{array}{l}\text { Post- } \\
* *\end{array}$ & $\begin{array}{l}\text { Plant } \\
* * \\
\text { survival }\end{array}$ \\
\hline Moncerin & 23.33 & 23.33 & 53.34 & 33.33 & 13.33 & 46. 67 & 23.33 & 13.33 & 63.64 & 20.00 & 20.00 & 60.00 \\
\hline $\begin{array}{l}\text { Vitavax } \\
\text { Thiram }\end{array}$ & 20.00 & 20.00 & 60.00 & $\begin{array}{l}16 . \\
67\end{array}$ & 10.00 & 73.33 & $\begin{array}{l}16 . \\
67\end{array}$ & 10.00 & 73.33 & $\begin{array}{l}16 . \\
67\end{array}$ & 6.67 & 76.66 \\
\hline Rizolex-T & 23.33 & 10.00 & 66.67 & 26.67 & 10.00 & 63.33 & 20.00 & 10.00 & $\mathbf{7 0 . 0 0}$ & 23.33 & 10.00 & 66.67 \\
\hline Tashgarin & 30.00 & 10.00 & 60.00 & 23.33 & 10.00 & 66.67 & 30.00 & 0.00 & 70.00 & 26.67 & 6.67 & 66.67 \\
\hline S. rolfii & 100.00 & 0.00 & 0.00 & 93.24 & 6.67 & 0.00 & 89.91 & 10.00 & 0.00 & 83.33 & $\begin{array}{l}16 . \\
67\end{array}$ & 0.00 \\
\hline $\begin{array}{l}\text { Control } \\
\text { (Non- } \\
\text { treated soil) }\end{array}$ & 0.00 & 0.00 & 100.00 & 0.00 & 0.00 & 100.00 & 0.00 & 0.00 & 100.00 & 0.00 & 0.00 & 100.00 \\
\hline
\end{tabular}

chitinases, $\beta$-1, 3-glucanases and cellulases which are important features of mycoparasites for the colonization of their host fungi (Hadar \& Taylor, 1984).

Coating of pepper seeds with $T$. harzianum decreased the percentages of damping -off , especially cvs. California wonder, and 'Anaheim M compared to the treatments inoculated with $S$. rolfsii only. These results are in agreement with those obtained by Okigbo and Ikediugwu (2000) and Serra and Sliva Gilson (2005).

Further experiments were carried out to test the fungicidal effect of four fungicides on reducing the incidence of damping-off of pepper.

The results demonstrated that no growth of $S$ rolfii was recorded when all the tested fungicides, i.e., Rizolex-T, Vitavax Thiram, Tashgrin and Moncerin were added at 100ppm to PDA medium, while the fungal growth reached $90 \mathrm{~mm}$ when $5 \mathrm{ppm}$ concentration was used. On the other hand, the least inhibition of the fungal growth was recorded when Tashgrin was added to PDA medium at 50ppm followed by Vitavax Thiram and Moncerin at the same concentration. These results are in agreement with those obtained by Abada (1994) and Yaqub and Saleem (2006).

The tested fungicides, i.e., Rizolex-T, Vitavax -Thiram, Tashgrin and Moncerin decreased the percentages of damping- off of the tested cvs. Vitavax -Thiram gave the highest decrement of pre- and post- emergence damping -off of all pepper cvs., specially Anaheim $\mathrm{M}$ and California Wonder followed by Rizolex-T. These results are in agreement with those given by Biswas and Sen (2000) and Abd El -Kareem et al. (2004).

\section{REFERENCES}

Abada K. A. (1994). Fungi associated with root rot disease of pepper and some factors affecting disease incidence. Proc of the $7^{\text {th }}$ 
Cong of Egypt, Phytopathol. Soc., Giza, Egypt: 219-226.

Abd El-Kareem F.A., Abd-Alla M.A., El-Gamal N. G. and El-Mougy N. S. (2004). Integrated control of lupin root rot disease in solarized soil under greenhouse and field conditions. Egypt. J. Phytopathol, 32:4963.

Abiaa K. and Muhammed S. H. (2008). Variabilily among isolates of Sclerotium rolfsii associated with collar rot disease of chickpea in Pakistan .Pak.Bot,40(1):453460.

Attia M.F and Abada K. A. (1994). Control of wilt and root rot diseases of pepper. Proc of the $7^{\text {th }}$ Cong. of Egypt. Phytopathol. Soc., Giza, Egypt, 397-409.

Bankole S.A. and Adebanjo A. (1998). Efficacy of some fungal and bacterial isolates in controlling wet rot diseases of cowpea caused by Pythium apanidermatum. J. plant. Protect. Tropics, 11:37-43.

Barnett H.L. and Hunter B. B. (1971). IIIustrated genera of imperfect fungi. Minnesota Burges Pup Co.241pp.

Biswas K. K and Sen C. (2000). Management of stem rot of groundnut caused by Sclerotium rolfsii through Trichoderma harzainum. Indian Phytopath,53(3):290-295.

Booth C. (1971). The Genus Fusarium. Commonwealth Mycological Institute, Kew,Surrey,England. 237p.

Booth C and Waterston J. M. (1964).Descriptions of Pathogenic Fungi and Bacteria. Commonwealth Mycological Institute, Ferry lans, Kew, Surrey, England.

Daami R. M., Jabnnoun K. H., Ayed F., Hibar K and ELMahjoub M. (2007). First report of Sclerotium rolfsii causing a typical soft rot on potato tubers in Tunisia. Tunisian Journal of Plant Protection, 2:59-62.

Di Pietro A. (1995). Fungal antibiosis in biocontrol of plant diseases. Chapter 20 In: Allelopathy: Organisims, Processes and Applications. (Eds; Inderjit, Dakshini, K. M. M. and Einhellig, F. A). p. 271-279.

EL -Mohamedy R. S., Abd Alla M. A and Badiaa R. I. (2006). Soil amendment and seed bio-priming treatments as alternative fungicides for controlling root rot disease on cowpea plants in Nobaria province. Research Journal of Agricultural\& Biological Sciences, 2 (6)391-398.

Fisher R. A. (1948).Statistical Methods for Research workers. Oliver and Boyd,
London.

Gilman J. C. (1957). A Manual of Soil for Fungi. Cambridge Univ. Press, Ames. Iowa, U. S. A. $450 \mathrm{pp}$.

Hadar Y. H and Taylor A. C. (1984). Evaluation of Trichoderma koningii and T. harzianum from New York soil for biological control of seed rot caused by Pythiuum sp. Phytopathology 74:106109.

Jin-Hyeuk K., Hyeong-Jin and Chang- Seuk P. (2008). Occurrence of bulb rot of Allium victorialis var. platyphyllum caused by Sclerotium rolfsii in Korea. Plant Pathol, J.24 (1):90-92.

Maurya S., Rashmi S., Singh D. P and Singh H. B. (2008). Management of collar rot of chickpea (Cicer arietinum) by Trichoderma harzianum and plant growth promoting rhizobacteria .Journal of Plant Protection Research, Indian, 48(2):347-354.

Muhammad S. and Amusa N. A. (2003). In-vitro inhibition of growth of some seedling blight inducing pathogens by compost-inhabiting microbes. African Journal of Biotechnology, 2 (6):161-164.

Muskhazli N. I. and Nor Farizan T. (2006). Production of bioactive compounds by Bacillus subtilis against Sclerotium rolfsii. Malaysian Journal of Microbiology, 2(2):19-23.

Okereke V.C. and Wokocha R.C. (2006). Effects of some tropical plant extracts, Trichoderma harzianum and captan on the damping -off disease of tomato induced by Sclerotium rolfsii .Agricultural Journal, 1(2):52-54.

Okereke V.C. and Wokocha R. C. (2007). In vitro growth of four isolates of Sclerotium rolfsii Sacc in the humid tropics. African Journal of Biotechnology, 6(6):1879-1881.

Okigbo R. N and Ikediugwu F. E. (2000). Studies in biological control of post-harvest rot in Yams (Dioscrea spp) using Trichoderma viride. J. Phytopathol, 148: 235-240.

Palaiah P., Adiver S. S., Kumara O. K and Chandrappa S. J. (2007). Sensitivily of Sclerotium rolfsii Sacc. isolates to different agrochemical and cultural filtrates of bioagents. Karnataka Journal Agric Science, 20 (2): 422-423.

Salt G. A. (1981). Factors affecting resistance to root-rot and wilt diseases. P. 259-277. in G. Hawiten and C. Webl (eds.)." Faba bean 
improvement" (C.f. Egypt. J. Appl. Sci., 7: 242-261, 1992).

Serra I. M and Sliva Gilson S (2005). Biological and physiological characterization of Isolates obtained from green pepper in the state of Maranhao. Fitopathol. Bars (online), 30:61-66.

Snedecor G. W and Cochran W. G. (1967).Statistical Methods $6^{\text {th }}$ ed. The lowa State Univ. Press, Ames, lowa, U.S.A.

Snyder W. C. and Hansen H. N. (1940). The species concept in Fusarium. Am. J. Bot. 27: 66-67.
Yaqub Fouzia and Saleem S. (2005). Pathogenicity of Sclerotium rolfsii and effect of inoculum density on colonization of mungbean and sunflower roots. Pak. J. Bot, 37(1): 175-180.

Yaqub Fouzia and Saleem S. (2006). Effect of fungicides on In vitro growth of Sclerotium rolfsii, Pak. J. Bot. 38(3): 881-883.

Young F. E., Tupper J and Strominger J. L. (1974). Autolysis of cell walls of Bacillus subtilis mechanism and possible relationship to competence. J. Biol. Chem. 249: 3600-3602.

\section{المقاومة الحيوية والكيميائية لمرض سقوط بادرات نباتات الفلقل \\ Sclerotium rolfsii Sacc. المتسبب عن الفئرات

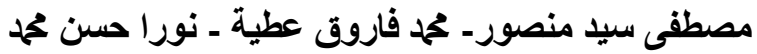 \\ قسم أمر اض النبات ـ كلبة الزر اعة ـ جامعة القاهرةـ الجيزة ـ مصر}

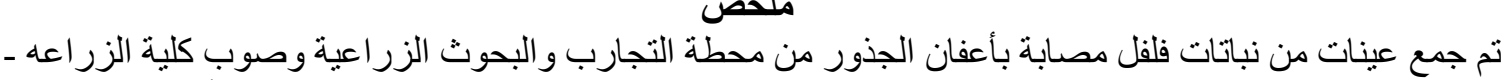

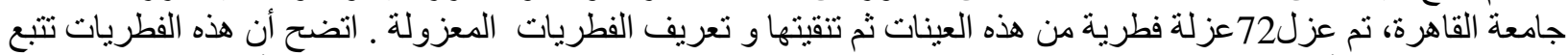

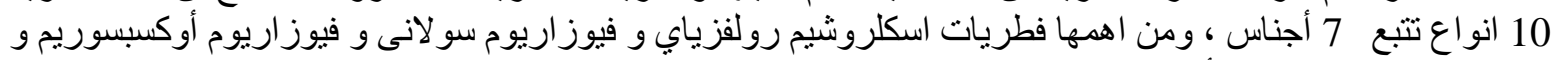

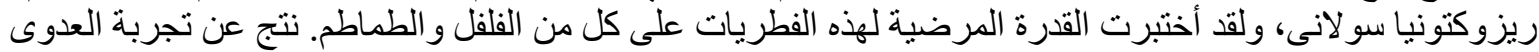

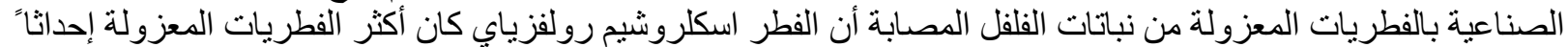

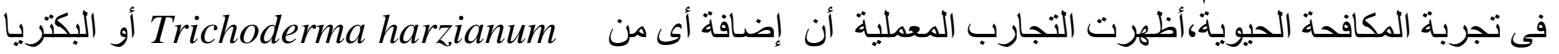
Bacillus subtilis

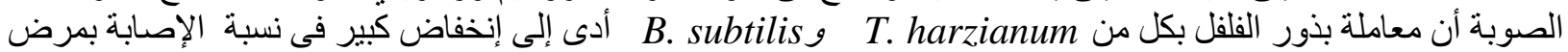

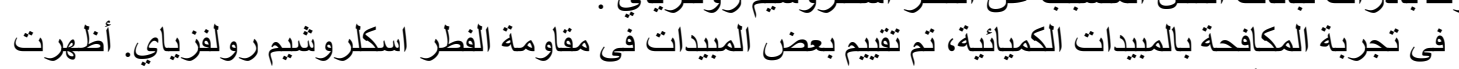

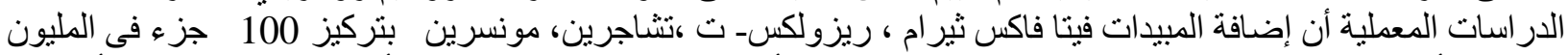

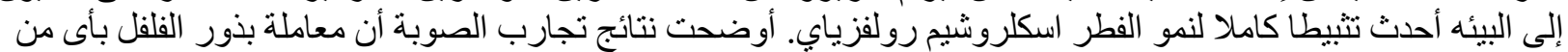

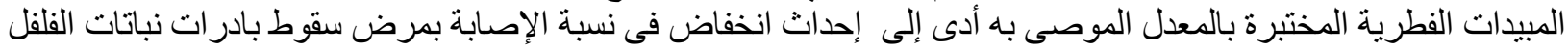
المنسبب عن الفطر اسكلروشيم رولفزياتي.

المجلة العلمية لكلية الزر اعة - جامعة القاهرة ـ المجلد (61) العدد الثالث (يوليو 2010):332-339. 